Schulich School of Law, Dalhousie University

Schulich Law Scholars

Articles, Book Chapters, \& Blogs

Faculty Scholarship

$12-2019$

\title{
Reverse Contributors? African State Parties, ICSID, and the Development of International Investment Law
}

Olabisi D. Akinkugbe

Dalhousie University Schulich School of Law, olabisi.akinkugbe@dal.ca

Follow this and additional works at: https://digitalcommons.schulichlaw.dal.ca/scholarly_works

Part of the International Law Commons, and the Law and Economics Commons

\section{Recommended Citation}

Olabisi D Akinkugbe, "Reverse Contributors? African State Parties, ICSID, and the Development of International Investment Law" (2019) 34:2 ICSID Rev 434.

This Article is brought to you for free and open access by the Faculty Scholarship at Schulich Law Scholars. It has been accepted for inclusion in Articles, Book Chapters, \& Blogs by an authorized administrator of Schulich Law Scholars. For more information, please contact hannah.steeves@dal.ca. 


\title{
Reverse Contributors? African State Parties, ICSID, and the Development of International Investment Law
}

\author{
Olabisi D. Akinkugbe*
}

\begin{abstract}
International investment disputes involving African states before the International Centre for Settlement of Investment Disputes (ICSID) have generated significant critical inquiry. Yet, accounts of their contribution to the development of international investment law as a result of these dispute are limited. This article addresses this gap. It examines the contribution of some of the high-profile ICSID disputes involving African states to the development of international investment law. Notwithstanding the charges against African States in ICSID, I contend that the involvement of African States in ICSID Disputes has contributed to the development of international investment law. In particular, the jurisprudence that these ICSID case law has generated, not only affirm principles of international investment law, but more importantly, have opened new paths over the years for the development of international investment law.
\end{abstract}

\section{Introduction}

Foreign direct investment is a critical component of the external source of finance for many developing countries. ${ }^{1}$ The mechanisms for the settlement of disputes between multinational or transnational corporations (as investors) and the states have been contentious. ${ }^{2}$ In the context of

\footnotetext{
* Assistant Professor, Schulich School of Law, Dalhousie University, Halifax, N.S., Canada. Ph.D., (University of Ottawa); LLM (University of Toronto), LLB (Hons) (University of Lagos, Nigeria), email: Olabisi.akinkugbe@dal.ca. I thank Professor Makane Moïse Mbengue for the invitation to contribute to this ICSIDReview special issue on Africa and the ICSID System. Thanks also to the anonymous peer-reviewers and to Prof. James Thuo Gathii for their helpful feedback. The usual caveats apply.

${ }^{1}$ According to UNCTAD, "FDI [Foreign Direct Investment] inflows to Africa are forecast to increase by about 20 per cent in 2018, to $\$ 50$ billion. The projection is underpinned by the expectation of a continued modest recovery in commodity prices, and by macroeconomic fundamentals. In addition, advances in interregional cooperation, through the signing of the African Continental Free Trade Area (AfCFTA) could encourage stronger FDI flows in 2018. Yet Africa's commodity dependence will cause FDI to remain cyclical." UNCTAD World Investment Report 2018, "Investment and New Industrial Policies", online: https://unctad.org/en/PublicationsLibrary/wir2018 en.pdf; Olabisi D. Akinkugbe and Sara Seck, "2017 Developments in Home and Host State Policy Responses to Foreign Direct Investment", in Yearbook on International Investment Law \& Policy 2017, Lisa E. Sachs, Lise J. Johnson, and Jesse Coleman (eds.), (Oxford University Press), pp. 49-64

At the continental level, international investment regime in Africa and the settlement of investment disputes is at a unique cross-road. There are regimes at the regional and national levels for the protection of foreign direct investment. Most recently is contentious debate on the 'Africanization' of international investment law as championed by the Pan-African Investment Code. See, Makane Moïse Mbengue and Stefanie Schacherer, "The 'Africanization' of International Investment Law: The Pan-African Investment Code and the Reform of the International Investment Regime", (2017) 18:3 The Journal of World Investment \& Trade, pp. 414-448; Erik Denters and Tarcisio Gazzini, "The Role of African Regional Organizations in the Promotion and Protection of Foreign Investment" (2017) 18:3 The Journal of World Investment \& Trade, pp. 449-492.

For an alternative argument, see, Won Kidane, "Contemporary International Investment Law Trends and Africa's Dilemmas in the Draft Pan-African Investment Code", (2018) Vol. 50 The Geo. Wash. Int'l L. Rev., pp. 523-579. (Arguing that Africa confronts significant 'dilemmas' with the Code once situated in the context of historical, extant and developing trends in international investment law. In Kidane's view, "the code does not resolve Africa's dilemmas; it merely codifies them.")

${ }^{2}$ Leon E. Trakman, "The ICSID Under Siege", (2012) Vo. 45 Cornell International Law Journal, pp. 604-663. (Evaluating the criticisms leveled at the ICSID and contending that "a contrite and diffident defense of the ICSID is
} 
the resolution of investor-state disputes before the International Centre for the Settlement of Investment Disputes (ICSID), there are skeptics and optimists of the forum. ${ }^{3}$ ICSID's paramount objective is to "promote a climate of mutual confidence between investors and states favourable to increasing the flow of resources to developing countries under reasonable conditions." 4 Now in its fifty-second year, in 2018, 57 new cases were registered and ICSID administered 279 "the greatest number of cases ever administered in a single year." $19 \%$ of the disputes registered in 2018 under the ICSID Convention and additional facility rules by region involved subSaharan African states. ${ }^{6}$ Between 1972 and 2017, African states have been a party to at least 144 investor-state ICSID cases. ${ }^{7}$

The participation of African state parties in ICSID administered investor-state disputes has been fierce and is far from settled. ${ }^{8}$ On the one hand, some scholars opine that African states were critical actors in the process that led to the establishment of ICSID and as such were conscious of the transformative potential of the ICSID system for the economic development of their economies. ${ }^{9}$ On the other hand, a different strand of scholarship that is more critical argues that colonial and post-colonial factors provide important context that illuminate the power asymmetry that were embedded in the establishment of ICSID. As such, they are less optimistic and perhaps more sceptical of the dispute mechanism and its claim to equality of parties among other factors. At the heart of these views emerges a murky narrative of the participation, and possibly

that its problems can be ascribed to the complexity of the multiple layers of investment law and that ICSID arbitration is one among multiple means of solving conflicts with real human, social and political potency. As such, it should not be construed as an end in itself.)

${ }^{3} \mathrm{M}$. Sornarajah, Resistance and Change in the International Law on Foreign Investment, (Cambridge: Cambridge University Press, 2015); [*]

${ }^{4}$ Ibrahim T.I. Shihata, "Towards a Greater Depoliticization of Investment Disputes: The Roles of ICSID and MIGA", (1992: Washington DC, World Bank), 1-32, pp. 5-6 Online: http://documents.worldbank.org/curated/en/335931468315286974/Towards-a-greater-depoliticization-ofinvestment-disputes-the-roles-of-ICSID-and-MIGA

${ }^{5}$ ICSID, 2018 Annual Report, (Sept. 6, 2018) p. 11. This was a 16\% increase over the number of cases registered in 2017.

${ }^{6}$ Ibid.

7 Paul-Jean Le Cannu, "Foundation and Innovation: The Participation of African States in the ICSID Dispute Resolution System", (2018) ICSID Review, pp. 1-45, pp. 40-45 (List of ICSID Cases involving African State Parties); Won Kidane, "The China-Africa Factor in the Contemporary ICSID Legitimacy Debate" (2014) Vol. 35, No.3, University of Pennsylvania Journal of International Law, pp. 560-604, pp. 624-673.

${ }^{8}$ Won Kidane argues that "When the World Bank asked the newly independent African states to join ICSID in 1964, they were rather unsure of what it meant for them beyond the promise of increased foreign investment ... Then, predictably, many African states appeared before ICSID tribunals over the years, accused of unlawful expropriation and denial of justice ... With almost no participation in the decision-making process, ... the African states continued to accept the "creditors' interpretation" of the investment treaties with their wealthier and more powerful partners." Won Kidane, "Contemporary International Investment Law Trends and Africa's Dilemmas in the Draft Pan-African Investment Code”, (2018) Vol. 50 The Geo. Wash. Int'l L. Rev., pp. 523-579, pp. 533-534.

9 "... fifteen of the twenty instruments of ratification, the deposit of which brought the ICSID Convention into force, came from African States - Benin, Burkina Faso, the Central African Republic, Chad, the Republic of the Congo, Côte d'Ivoire, Gabon, Ghana, Madagascar, Malawi, Mauritania, Nigeria, Sierra Leone, Tunisia, and Uganda (the other five came from Iceland, Jamaica, Malaysia, the Netherlands and the United States)." Judge Charles N. Brower and Michael P. Daly, "A Study of Foreign Investment Law in Africa: Opportunity Awaits", online: $<\underline{\text { https://www.arbitration- }}$

icca.org/media/7/82088225980224/brower daly a study_of foreign investment law in africa.pdf> pp. 4-10. ("Africa's Historical Role Within Foreign Investment Law") p. 5; AA Agyemang, "Äfrican states and ICSID arbitration", (1988) Comp. \& Int'l L.J. S. Afr., pp. 177 - 189, (examining "the extent of African utilization of ICSID for purposes of settling investment disputes and the factors which possibly account for such utilization or nonutilization of the facilities of the Centre."), p. 177. 
contribution of African states to the development of international investment law on the one hand, and ICSID case law, on the other hand.

Significant critical work has been done that focused on the marginality of African states in the evolution of international law and other international legal fields. ${ }^{10}$ Whereas theoretical approaches such as Third World Approaches to International Law (TWAIL), and in the context of continental investment law, the 'Africanization' of international investment law thesis championed by Makane Mbengue, has attempted to reclaim some of Africa's role in this process, albeit not without its complexity, it is important to avoid critique that inadvertently perpetuates the 'dilemmas' - as Won Kidane conceptualizes - of the role of African states in the on-going development of international legal fields.

Particularly, in the context of contentious 'organic' or non-organic evolution of international investment law, while African states may not have participated equally or at all in some of the institutions or organizations and the dispute settlement that demarcate the contours of international law and international investment law, this article argues that such analysis should not foreclose the possibility of accounting for subsequent contributions of African states to the development of the regimes, especially, in the post-colonial era. As a caveat, the case for conceptualizing African state parties as reverse contributors to the development of international investment law and ICSID case law should not be constructed as blind to the power relations that are embedded in the international legal structures that constrain African states. Similarly, this is not an argument for African exceptionalism as it may be possible to draw similar arguments in the context of other regions that comprise the Third World. Rather, while I acknowledge these challenges, this article contributes to the scholarly work that tease out African states' contribution, despite the murkiness of the critical debates. ${ }^{11}$ Put conversely, an analysis of the contribution of African states to the development of international investment law as undertaken in this article, does not undermine the on-going critique of the work of many scholars, rather, it strengthens it by illuminating nuanced implications that have arisen from the disputes involving African states.

Based on the analysis of some high-profile investment disputes involving African states, I contend that the jurisprudence emerging from these disputes have contributed to the development, shaping, evolution, and contour mapping of international investment law. While I acknowledge the critique that African states have mostly been involved in the investment disputes as Respondents, I argue that this fact should not limit our analysis of the contribution that the issues decided upon by the Arbitral Tribunal have made to the development and evolution of international investment law. Being a respondent in a dispute is not synonymous

10 Sundhya Pahuja, Decolonising International Law: Development Economic Growth and the Politics of Universality, (Cambridge University Press, 2011); ___ "The Postcoloniality of International Law", (2005) 46:2 Harvard International Law Journal, pp. 459-469; Obiora Chinedu Okafor, "Critical Third World Approaches to International Law (TWAIL): Theory, Methodology, or Both?”, (2008) 10 International Community Law Review, pp. 371-378; _ "Newness, Imperialism, and International Legal Reform in Our Time: A TWAIL Perspective", (2005) 43 Osgoode Hall Law Journal, pp. 171-191.

11 Paul-Jean Le Cannu, "Foundation and Innovation: The Participation of African States in the ICSID Dispute Resolution System", (2018) ICSID Review, pp. 1-45; Ibironke Odumosu-Ayanu, "International Investment Arbitration and Corruption Claims: An Analysis of World Duty Free v. Kenya" (2011) 4 Law and Development Review Article 5; Tsotang Tsietsi, "International Commercial Arbitration: Case Study of the Experiences of African States in the international Centre for Settlement of Investment Disputes", (2013) 47 The International Lawyer, pp. 249-271. 
with being passive in the matter. At a time when international investment law is under a significant call for transformation, there is an opportunity to also reflect on the contribution of African states in investment related disputes before the ICSID Tribunal overtime.

In Part I, I develop the thesis that high-profile investment disputes involving African states as respondents should be understood not simply for the substantive matters they resolve. Rather, by reconceptualizing the role of the African state respondents as reverse contributors to the jurisprudence that these disputes have produced, we are able to capture the value of these highprofile cases to the evolution and development of international investment law overtime. HighProfile international investment disputes involving African states are delineated by the fact that the substantive issues that the Tribunal issued awards or procedural orders on not only reinforce aspects of ICSID and international investment law rules, but they also clarify concepts and at other times deliberate on novel matters that no previous arbitral tribunal has ruled upon. In Part II, I analyze the contributions of these selected high-profile investment disputes involving African states by categorizing them into three (3) generations. The Frist-Generation of highprofile cases map investment disputes that occurred from the late 1970s to 1990s; the SecondGeneration then starts from 2000s to 2010; while the Third-Generation is from 2010 to the present. It is important to note that the periodization adopted in this article is not static nor are they intended to be interpreted as linear. Rather, they are fluid and overlapping and have been marked by a definite period for the purpose of analyses of the disputes over the 50 years of ICSID that was recently celebrated. In the concluding section of the article, I contend that looking back, despite the challenges and backlash that African states have faced as Respondents in ICSID arbitral disputes, international investment disputes involving African States have not only contributed to the development of international investment law, but African states continue to be an important player today with even better prospects for the future given the growing wave of arbitral regulatory regimes in the continent as well as future investment opportunities that will draw on foreign investors. ${ }^{12}$

\section{Part I}

\section{African State Respondents as Reverse Contributors in ICSID Investment Disputes}

In the context of international law scholarship, the Euro-centric antecedents and the participation of developing countries and African states in particular have been analyzed with significant academic rigour in the studies on resistance movements, anti-colonialism, and even in postcolonial African states. ${ }^{13}$ Similar questions loom with respect to the origins and evolution of

\footnotetext{
12 Judge Charles N. Brower and Michael P. Daly, "A Study of Foreign Investment Law in Africa: Opportunity Awaits", online: <https://www.arbitrationicca.org/media/7/82088225980224/brower daly a study of foreign investment law in africa.pdf> pp. 4-10. ("Africa's Historical Role Within Foreign Investment Law"); Won Kidane, "Alternatives to Investor-State Dispute Settlement: An African Perspective", Global Economic Governance Discussion Paper, January 2018

${ }^{13}$ See generally, Rajagopal Balakrishnan, International Law from Below: Development, Social Movements and Third World Resistance, (Cambridge University Press, 2003); James Thuo Gathii, "International Law and Eurocentricity" (1998) 9 European Journal of International Law, pp. 184-211; Anthony Anghie, "The Evolution of International Law: colonial and postcolonial realities", (2006) Vol. 27, No. 5, Third World Quarterly, pp. 739753.(sketching a history of the relationship between imperialism and international law in the evolution of international law from the $16^{\text {th }}$ century).
} 
international investment law. ${ }^{14}$ From this perspective, the history of Africa's 'dilemmas' as it relates to ICSID is intricately interwoven with the Eurocentric foundations of international investment law. ${ }^{15}$ For example, Won Kidane contends that "[t]he historical record clearly indicates that the only reason that the African states accepted ICSID is because they thought that they had to do so in order to attract private foreign investment to develop their ailing postcolonial economies." "I In this regard, the ratification of the ICSID Convention by African States not only has the potential for an enhanced flow of foreign investment but also, it affirms the sovereign status of African states in early post-colonial Africa. ${ }^{17}$ More recently, Kidane asserts further that:

"International investment law [IIL] comes with a very old and lingering historical baggage that continues to engender doctrinal confusion and outright suspicion ... IIL is not made by Africa, it was made for Africa as a replacement for colonial rules for the protection of capital." 18

Kidane conceptualizes ICSID creation as part of a robust plan that Joost Pauwelyn alluded to in his description of programs that were constructed and strategies for investment protection that were meant to avoid the economic collapse of the 1930s. While Kidane argues that it will be difficult to sustain Pauwelyn's claim that international investment law is "organic and incremental,"19 in probing Pauwelyn's incrementality and organic thesis on the origin of international investment law, Kidane inevitably inserts the controversial debate around Africa's role in the development of international law. ${ }^{20} \mathrm{~A}$ strand of the debate on the contribution of Africa to the development of international law centres around the role of African elites. The work of some of the African elite intellectuals that were involved in the development of the universal norms of public international law and by extension the negotiation, drafting and establishment of the ICSID Convention are critical.

\footnotetext{
${ }^{14}$ Zachary Douglas, Joost Pauwelyn, and Jorge E. Viñuales (eds.) The Foundations of International Investment Law: Bringing Theory into Practice, (2014: Oxford University Press); Georges Abi-Saab, "The third World intellectual in praxis: confrontation, participation, or operation behind enemy lines?" (2016) 37:11 Third World Quarterly, pp. 1957-1971.

15 Won Kidane, "Contemporary International Investment Law Trends and Africa's Dilemmas in the Draft PanAfrican Investment Code", pp. 528-534.

16 Won Kidane, "Alternatives to Investor-State Dispute Settlement: An African Perspective", Global Economic Governance Discussion Paper, January 2018; Won Kidane, "The China-Africa Factor in the Contemporary ICSID Legitimacy Debate”, (2014) 35 U. Penn. J. Int'l L. p. 559 at 585-86.) Daniel Behn, Tarald Berge \& Malcolm Langford, "Poor States or Poor Governance: Explaining Outcomes in Investment Treaty Arbitration" (2018) 38:3 Northwestern Journal of International Law \& Business, pp. 335-382.

17 Tsotang Tsietsi, "International Commercial Arbitration: Case Study of the Experiences of African States in the International Centre for Settlement of Investment Disputes", (2013) 47 The International Lawyer, pp. 249-271. (Questioning whether the membership of ICSID has necessarily resulted in increased investment flows).

18 Won Kidane, "Contemporary International Investment Law Trends and Africa's Dilemmas in the Draft PanAfrican Investment Code", p. 526.

19 Joost Pauwelyn, "Rational Design or Accidental Evolution? The Emergence of International Investment Law" in The Foundations of International Investment Law: Bringing Theory into Practice, Zachary Douglas, Joost Pauwelyn, and Jorge E. Viñuales (eds.) (2014: Oxford University Press), pp. 10-43

${ }^{20}$ For a more recent survey of these debates, see, James Thuo Gathii, "Africa and the History of International Law", Albany Law School Research Paper No. 48 of 2011/2012, Dieng, Adama in Jeremy Levitt (ed.) Mapping New Boundaries in African International Law (Hart Publishing, Oxford 2008); M. W. Mutua, '(Book Review) Africa: Mapping New Boundaries in international Law by Jeremy I. Levitt' (2010) 104 American Journal of International Law, pp. 532-538; Jeremy I. Levitt, "The African Origins of International Law: Myth or Reality? (2015) 19:113 UCLA Journal of International Law and Foreign Affairs, pp. 114-158.
} 
One of these elites whose work has been significantly scrutinized is Taslim Olawale Elias. ${ }^{21}$ Elias participated in the ICSID negotiation process as the Attorney-General of Nigeria. He later became a judge of the International Court of Justice. ${ }^{22}$ In heartily recommending the Preliminary Draft of the ICSID Convention, Elias described it as

"an attempt not only to restore the confidence of the investor but also to codify certain principles of customary law and to engage in the progressive development of international law, and he warmly recommended it." 23

James Gathii argues that Elias was innovative in his use of history to "reclaim or claim a place in international legal history for Africa" ... "because Elias sought not to reject international law for its legacy and participation in the colonization of Africa, but rather sought to use these legal tools as best as he could to reform international law to serve the newly independent countries." 24 Elias' support of ICSID came at a hopeful moment for Africa - right after decolonization and although Africa was experiencing its first series of internal challenges, Elias did not abandon his faith in the transformative potential of international law and of foreign investment. ${ }^{25}$

In relation to the praxis of international investment law, in his recent book, The Culture of International Arbitration, Kidane took on a "cultural critique of international arbitration."26 Drawing on his personal experiences from arbitral hearings, Kidane masterfully interrogates the cultural complexity that is embedded and are regularly confronted in the inner chambers of arbitral proceedings - many of which we do not get to hear because of the confidentiality of the process. ${ }^{27}$ In Kidane's view, contemporary international arbitration as characterized by a diversified user base must account for these variations in process and practice. Reviewing this book, Makane Moïse Mbengue and Elise Ruggeri Abonnat aptly describe "Kidane's analysis [a]s a legitimate reminder that the status quo is not an option as well as a prompt reminder ... that

${ }^{21}$ James Thuo Gathii, “A Critical Appraisal of the International Legal Tradition of Taslim Olawale Elias”, (2008) 21 Leiden Journal of International Law, pp. 317-349. The volume was dedicated to an examination of the works of leading international legal jurists.

22 Elias T. Olawale, Africa and the Development of International Law, [1972]

${ }^{23}$ ICSID, History of the ICSID Convention: Documents Concerning the Origin and Formulation of the Convention (1968) Volume II-1, p. 244

${ }^{24}$ Gathii, "A Critical Appraisal of the International Legal Tradition of Taslim Olawale Elias", p. 347.

25 Yet, at the time Elias wrote, there were other contemporaries such as Julius Nyerere who were critical and less optimistic of the transformative potential of international (investment) law. See, Jeannette Hartmann, "Development Policy-Making in Tanzania 1962-1982: A Critique of Sociological Interpretations", Philosophy, University of Hull, 1983 , online: https://halshs.archives-ouvertes.fr/tel-

01266236/file/THESES\%20\%28PHDs\%29\%20The\%20University \%20of\%20Hull\%20Development $\% 20$ Policymaking\%20in\%20Tanzania\%201962-1982\%20A\%20Critique \%20of\%20Sociological\%20Interpretations.pdf

${ }_{26}$ Won L. Kidane, The Culture of International Arbitration, (2017: Cambridge University Press), p. 4. Also see generally, Tom Ginsburg, "The Culture of Arbitration”, (2003) 36 Vand. J. Int'L Law, p. 1335.

${ }^{27}$ For example, following a vivid explanation of one of the proceedings he was involved, he notes:

"The problem - which is almost always framed in the context of the incompetence of the local representatives of the parties and witnesses who come from cultures outside of the cultures that dominate international arbitration - is almost never framed in the context of cultural competence of the tribunals to understand and serve the parties who selected them, or who make their selection possible, but, rather is framed as the cultural deficiency or incompetence of the parties or their representatives who appear before such tribunals." Kidane, P. 6, Ibid. 
"Not only must justice be done; it must also be seen to be done." ${ }^{28}$ Despite the fact that African states' participation in the status quo continues in "the same terrain of hegemonic international [investment] law," the seeds for potential change and reforms that address the critiques of ICSID lie with the liberal promises of international investment law. ${ }^{29}$

In this regard, other scholars such as Mark Fathi Massoud, have drawn attention to the intricate and mutuality of international arbitration and judicial politics in authoritarian states. Massoud argues that in the context of Sudan, a commitment to arbitration is a signal to investors that their concerns are its priorities and that "parties to a contractual agreement choose arbitration because of its flexibility in an uncertain business climate..." 30 According to Massoud, "authoritarian regimes, particularly those in politically fragile and resource-rich contexts, are agreeing to submit to international arbitration clauses in order to (1) promote investment or economic liberalization and (2) make promises to foreign investors that mitigate uncertainty in the event of a dispute." ${ }^{31}$ Regardless of the view one holds of ICSID, and the backlash against investment and arbitration, ${ }^{32}$ It is instructive to note as Ibrahim Shihata and Sergio Puig have stated that "ICSID should not be assessed solely on the basis of effects as an international adjudicatory body." 33

With the foregoing in mind, I now turn to the elaboration of the concept of African parties as reverse contributors. The participation of African states was critical to the establishment of ICSID. As Paul-Jean Le Cannu observes, "the distinctive role that African states played in shaping the nascent ICSID system set the stage for their continued contribution to its evolution." 34 Similarly, A.A. Agyemang declares that "judging from [the] role of African states in ICSID institutions ... African states ought to call [ICSID] their own and have confidence in to settle their investment disputes" 35 However, beyond their role in the establishment of ICSID, African states have been important actors in the development of ICSID jurisprudence. As at December 2017, African states has been involved as a party in over 140 disputes. Deriving from this high level of participation in disputes, I argue that the jurisprudence that emerges from these

\footnotetext{
${ }^{28}$ For a review of Kidane's book, Makane Moïse Mbengue and Elise Ruggeri Abonnat, (2017) Ethiopian Yearbook of International Law, 221-225, p. 225.

${ }^{29}$ Gathii, James Thuo, "The Agenda of Third World Approaches to International Law (TWAIL)" (December 20, 2018). Forthcoming in Jeffrey Dunoff and Mark Pollack (eds) International Legal Theory: Foundations and

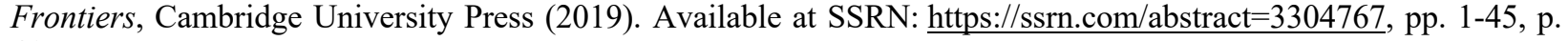
41.

${ }^{30}$ Mark Fathi Massoud, "International Arbitration and Judicial Politics in Authoritarian States”, (2014) 39:1, Law \& Social Inquiry, pp. 1-30

${ }^{31}$ Ibid, pp. 22-23.

32 Georges Abi-Saab, "The Third World intellectual in praxis: confrontation, participation, or operation behind enemy lines?" (2016) 37:11 Third World Quarterly, pp. 1957-1971.

33 Sergio Puig, "Recasting ICSID’s Legitimacy Debate - Towards a Goal-Based Empirical Agenda", (2013) 36:2 Fordham International Law Journal, pp. 466-504, p. 469. Ibrahim F. I. Shihata, "Towards a Greater Depoliticization of Investment Disputes: The Roles of ICSID and MIGA", (1986) 1:1 ICSID Review - Foreign Investment Law Journal, pp. 1-25; "ICSID should not be solely regarded as a mechanism for the settlement of investment disputes ... ICSID must be regarded as an instrument of international policy for the promotion of investments and of economic development." pp. 5-6

34 Cannu, "Foundation and Innovation: The Participation of African States in the ICSID Dispute Resolution System”, supra note 7, p. 3; Karel Daele, “Africa's Track Record in ICSID Proceedings”, Kluwer Arbitration Blog (30 May 2012), http://arbitrationblog.kluwerarbitration.com/2012/05/30/africas-track-record-in-icsid-proceedings/, (accessed 27 October, 2018); Judge Charles N. Brower and Michael P. Daly, "A Study of Foreign Investment Law in Africa: Opportunity Awaits", supra note 3; Won Kidane, "The China-Africa Factor in the Contemporary ICSID Legitimacy Debate", (2014) 35 U. Penn. J. Int'l L. p. 559 at 599.
}

35 A.A. Agyemang, p. 183. 
disputes has not only advanced substantive concepts in international investment law, but also clarified aspects of the discipline while simultaneously contributing to the development of ICSID case law and procedures.

As reverse contributors the focus is two-fold: (i) the fact that they are mostly respondent parties; and, (ii) the type of arguments that they have raised and the opportunity it has provided for the development of ICSID case law and by extension, the field of international investment law. Reverse contributors therefore denote the fact that while these states may not have been the claimants, their role as respondents who were actively involved in the cases, and in particular, the arguments they advanced and the reports of the tribunal in affirming or rejecting them, have advanced our understanding of international investment law rules and concepts. In other words, the primary focus is not on the fact that the arguments proffered by the states through their counsel have been adopted by the tribunal. Rather, it is in the overall outcome effect it has had for an elaboration of concepts and the provisions of the investment agreements out of which the dispute has arisen.

Reverse contributors as conceptualized in this article does not preclude critique nor does it signal at cooptation. To use Georges Abi-Saab's description, it also does not exclude 'operations behind enemy lines. ${ }^{36}$ In other words, while reform of the ICSID system is an on-going process, African states continue to be involved in disputes, hence, it is important to account for the role or value they add to the system simultaneously with the process of exposing the defects of the system. In this regard, African state parties are reverse contributors precisely because of the historical and contemporary complexity, power relations and rules of the game that discipline their involvement in ICSID arbitrations. As reverse contributors, they are not wedded to global capital lock, stock and barrel.

As reverse contributors in the substantive development of international investment principles, their push-back at different stages, strategies of defence, and willingness to not just accept the position of the investors or transnational corporations provided a rich opportunity overtime for the elaboration of the ICSID rules on various issues in international investment law while also pushing the boundaries to new areas. ${ }^{37}$ While a case-by-case country defence strategy is beyond the scope of this article ${ }^{38}$, there is a considerably wide array and complex permutations of the background factors that drive the approach of the various African states that have been involved in ICSID arbitration. ${ }^{39}$ As will become evident from the analyses of some high-profile ICSID cases in the next section, African countries engagement with ICSID and the consequential elaboration of ICSID rules have consistently grown over the first fifty years of ICSID - as the saying goes, it takes two to tango!

\footnotetext{
${ }^{36}$ Georges Abi-Saab, "The Third World intellectual in praxis: confrontation, participation, or operation behind enemy lines?” (2016) 37:11 Third World Quarterly, pp. 1957-1971, 1964.

37 Michael Waibel, Asha Kaushal, Kyo-Hwa Chung \& Claire Balchin (eds), The Backlash Against Investment Arbitration: Perceptions and Reality, (Hague: Kluwer Law, 2010)

${ }^{38}$ Julia Calvert, "State Strategies for the Defence of Domestic Interest in investor-State Arbitration", International Institute for Sustainable Development, February 29, 2016. Online: https://www.iisd.org/itn/2016/02/29/statestrategies-for-the-defence-of-domestic-interests-in-investor-state-arbitration-julia-calvert/

${ }^{39}$ Langford, M., Behn, D., \& Fauchald, O. "Backlash and State Strategies in International Investment Law" in T. Aalberts \& T. Gammeltoft-Hansen (Eds.), The Changing Practices of International Law, pp. 70-102. (2018: Cambridge: Cambridge University Press)
} 
Viewed from this perspective, African states, as reverse contributors to ICSID jurisprudence and case law, are indeed shapers of the ICSID policy development, beyond the critical role they played in the establishment of the system. In Part II, I examine some of the high-profile disputes involving African states in respect of which consequential rulings have been delivered by the ICSID Tribunal.

\section{Part II}

\section{Generations of Disputes involving African States over the International Investment Years}

As of December 31 2017, African states have been involved in one hundred and seventy one (171) cases before the ICSID Tribunal. ${ }^{40}$ The transnational economic relations between postcolonial African states and investor industrialized corporations have generated a significant amount of investment related disputes. The analysis of some of the investment disputes involving African countries is undertaken in the ensuing sections under three generations. The periodization of the three generations is overlapping and should not be viewed as linear. The type of disputes the parties bring also reveal the on-going change and expansion in the development of international investment law to areas and issues outside of core foreign investment protection and expropriation.

\section{First Generation: 1970s - 1990s}

The First Generation of cases are the earliest engagement of African Sates with the ICSID system. ${ }^{41}$ These disputes were fundamental in the early stages of ICSID as they underpinned ICSID's future development. It is indeed reflective of the reverse contributor status of African states described in this article that the first dispute before ICSID,${ }^{42}$ the first case where an award was rendered where a state was the claimant, ${ }^{43}$ and the first successful counter-claim, ${ }^{44}$ involved different African states. ${ }^{45}$ In this regard, the high-profile disputes that I will discuss include Holiday Inns S.A. \& Others v. Morocco; ${ }^{46}$ Societe Ltd. Benvenuti et Bonfat Srl (Italy) v. The Government of Congo ${ }^{47}$; The Pyramids Case ${ }^{48}$; and the Klockner v. Cameroon disputes. ${ }^{49}$

The Holiday Inns S.A. \& Others v. Morocco (Holiday Inns) dispute popularly dubbed as the first 'World Bank' arbitration had Morocco as a Respondent. ${ }^{50}$ Registered in 1972, it was the first request for arbitration under the ICSID Convention. Following initial negotiation between

\footnotetext{
${ }^{40}$ For a list of all these cases, see, Cannu, supra note 7, pages 40-45.

${ }^{41}$ Lynch, "The International Centre for the Settlement of Investment Disputes: Selected Case Studies" (1981-1983)

7 International Trade Law Journal, p. 306.

${ }^{42}$ Holiday Inns S.A. \& Others v. Morocco, ICSID Case No. ARB/72/1 (1972).

${ }^{43}$ Adriano Gardella SpA v. Cote d'Ivoire, ICSID Case No. ARB/74/1, Award rendered in 1977.

${ }^{44}$ Maritime International Nominees Establishment v. Republic of Guinea, ICSID Case No. ARB/84/4

${ }^{45}$ Gabon $v$ Societe Serete SA, ICSID Case No. ARB/76/1.

${ }^{46}$ Holiday Inns S.A. \& Others v. Morocco, ICSID Case No. ARB/72/1 (1972).

${ }^{47}$ Societe Ltd. Benvenuti et Bonfat Srl (Italy) v. The Government of Congo,

${ }^{48}$ Southern Pacific Properties (Middle East) Limited v. Arab Republic of Egypt, ICSID Case No. ARB/84/3. Online: http://icsidfiles.worldbank.org/icsid/ICSIDBLOBS/OnlineAwards/C135/DC671_En old.pdf

${ }^{49}$ ICSID Case No. ARB/81/2.

${ }^{50}$ Pierre Lalive, “The First 'World Bank' Arbitration (Holiday Inns v. Morocco): Some Legal Problems”, (1980) 51:1 British Yearbook of International Law, pp. 123-162. The article also provides a very useful account of the facts of the dispute.
} 
representatives of the parties to the dispute regarding boosting the tourism industry in Morocco via the construction of hotels, the parties entered into a 'basic agreement' joint venture with the objective of establishing and operating in Morocco four Holiday Inn hotels of 300 rooms each, namely in Rabat, Marrakesh, Fez and Tangiers. As part of its obligations, the Moroccan government undertook to provide loans and incentives to the investors towards the completion of the project. For business related and tax decisions, the investors opted to create a separate affiliated company: Holiday Inns S.A. Glarus, and Occidental Hotels of Morocco. As at when the parties signed the basic agreement for the project, Holiday Inn S.A. Glarus, was in the process of being incorporated while Occidental Hotels of Morocco had in fact not been established. The Agreement between the parties provided for ICSID arbitration in the event of a dispute. Despite progress in the construction of the hotels, there was trouble between the parties in relation to the financing as the Moroccan government not only stopped the payment they were required to make, but also refused to proceed with the incentives it had promised. Based on the foregoing, the Claimant commenced the ICSID arbitration. For various reasons, Morocco objected to ICSID jurisdiction. ${ }^{51}$ Amongst other things, Holiday Inns dispute therefore raised the question: when is a contracting state party bound by the ICSID arbitration system? As well as what it means to be treated as the "national of another Contracting State" for the purpose of Article 25(2)(b) of the ICSID Convention. ${ }^{52}$ The tribunal rejected Morocco's arguments holding that the dispute came under the ambit of the Convention based on the agreement of the parties. According to the Tribunal, it is of the opinion that the ICSID Convention allows parties to "subordinate the entry into force of an arbitration clause to the subsequent fulfillment of certain conditions, such as the adherence of the States concerned to the Convention, or the incorporation of a company envisaged under the agreement." 53 The tribunal, however, agreed with the government of Morocco that the chain of hotels being built did not come under the umbrella of "national of another Contracting State." 54

If the Holiday Inn dispute indicated the circumstances when a national judiciary will not be seized of jurisdiction when parties have agreed to arbitration, Societe Ltd. Benvenuti et Bonfat Srl (Italy) v. The Government of Congo provides another early investment dispute involving African state before the ICSID where the clarification of the jurisdiction and applicability of the ICSID arbitration system vis-à-vis the potential role of a local court is examined. ${ }^{55}$ The dispute arose out of a joint venture between the claimant Italian firm and the Government of the People's Republic of Congo for the establishment of a local company. The local company named PLASCO will manufacture plastic bottles for mineral water and the ownership structure is divided into $60 \%$ and $40 \%$ stakes respectively for the government and the investor. As part of its obligations, the government was not only required to pay a certain percentage of the company's share capital, but also, guarantee the financing of the new company, grant preferential tax status among other measures aimed at protecting the company; while the investor will in addition to contributing its

\footnotetext{
${ }^{51}$ For example, "Morocco argued that the parties lacked the capacity to agree to ICSID arbitration because, at the date of the 1966 basic agreement, neither Morocco nor Switzerland was a party to the ICSID Convention... Furthermore, the company itself was not yet a legal entity under Swiss law." W. Michael Tupman, "Case Studies in the Jurisdiction of the international Centre for Settlement of Investment Disputes", (1986) 35:4 The International and Comparative Law Quarterly, pp. 813-838, p. 818.

52 Ibid.

${ }^{53}$ Continuing, the Tribunal noted that "On this assumption, it is the date when these conditions are definitely satisfied, as regards one of the involved, which constitutes in the sense of the Convention the date of consent by that party." Ibid, p. 818.

${ }^{54}$ Ibid, p. 819.

${ }^{55}$ Ibid, p. 823.
} 
own share capital, operate the plan and guarantee the marketing of the bottles produced ${ }^{56}$ As events unfolded, the government of Congo not only failed to meet its obligations under the agreement and even after the investor stepped in to mitigate the situation, but also frustrated any possibility of fruition from the mitigation by the investor. Eventually, the government disposed PLASCO of the plant and its company offices. The agreement provided that dispute arising will be settled under the ICSID arbitration. When the investor commenced arbitration under the ICSID rules, the government of Congo contended the Centre's jurisdiction on the grounds that there was a requirement for the exhaustion of local judicial remedies by the investor prior to the ICSID proceedings ${ }^{57}$, and that the doctrine of lis pendens required that the action must in any case be suspended because of a criminal proceeding against a representative of the investor. While the ICSID Tribunal did not make any pronouncement on the question of exhaustion of remedies before the judiciary; the Tribunal rejected the lis pendens contention by the government of Congo as the identity of the parties and the subject matter of dispute were different. While the priority accorded to ICSID arbitration in terms of exclusivity has been reinforced, this dispute nevertheless provided as insight into the circumstances where the pendency of an action before a national court may have impact on an ICSID proceeding.

The Southern Pacific Properties (Middle East) Limited v. Arab Republic of Egypt (Pyramids Case $)^{58}$ dispute provides another illustration of the significance of the jurisprudence that involves African states. Although the award in this case was made in 1992, the case had begun since the 1980s, hence, I categorize it as part of the First-Generation disputes. The case is particularly worthy of note because for the first time, an ICSID Tribunal upheld its jurisdiction based on the Egyptian law. As for the facts, in 1974, Southern Pacific Properties (SPP), entered into agreements with Egypt to establish a joint venture with a view to developing an international tourist complex at the Pyramids Oasis in Egypt. SPP's Egyptian subsidiary, SPP(ME), held 60\% of shares in joint venture company, with the remaining $40 \%$ owned by the Egyptian partner. The project went ahead until 1978 when, as a result of parliamentary opposition, the Government effectively cancelled the project placing the joint venture company in judicial trusteeship. In 1984, the Claimants decided to take the matter before an ICSID Tribunal, pursuant to Egyptian Law which contained an ICSID arbitration provision. The Claimants maintained that Egypt's actions violated the agreements and amounted to expropriation of the investment, and thus claimed compensation for the value of their investment in the joint venture company plus interest. In upholding Egypt's actions as a lawful expropriation of the Claimants' investment, the Tribunal assumed jurisdiction by placing reliance on Egyptian and international law. The significance of this case has been analyzed by scholars. ${ }^{59}$

Further in the context of First-Generation investment disputes involving Africa states that has contributed to the development of international investment law is the case of Klockner $v$.

\footnotetext{
56 Ibid.

${ }^{57}$ Summarizing the relevant provisions of the agreement between the parties, Tupman, stated that "Article 25 of the PLASCO by-laws provided that any dispute between the shareholders concerning corporate matters, or between the shareholders and the company, "which have not been settled either by the competent courts of the corporate jurisdiction or, by negotiation, shall be arbitrated under the [ICSID] Convention." Ibid, p. 824.

58 W. Laurence Craig, "The Final Chapter in the Pyramids Case: Discounting an ICSID Award for Annulment Risk", (1993) 8:2 ICSID Review - Foreign Investment Law Journal, pp. 264-293.

59 For example, see, Jan Paulson, “Arbitration without Privity”, (1995) 10:2 ICSID Review - Foreign Investment Law Journal, pp. 232-257.
} 
Cameroon. ${ }^{60}$ Klockner is historic in the sense that it was the first investment dispute that provided an avenue for an arbitral decision on the concept of annulment. In this regard, the case carries on the theme of clarifying and affirming ICSID rules on annulment, which, in the context of ICSID arbitration, is a remedy of an extraordinary nature in the sense that ICSID awards are final and binding on the parties to the dispute. ${ }^{61}$ Annulment is one of the hand-full of post-award remedies available under the ICSID Convention as an exceptional recourse to safeguard against the violation of fundamental legal principles relating to the process. ${ }^{62}$

Klockner, a German company, and two subsidiaries of Klockner instituted an arbitration proceeding against Cameroon and the Societe Camerounaise des Engrais under the ICSID proceeding. The arbitration which commenced in 1981 ended in 1983 with an arbitral award and a dissenting opinion. ${ }^{63}$ A year later, Klockner sought to have the award annulled under the provisions of Article 52 of the ICSID Convention. In 1985, an ad hoc Committee that was established pursuant to the provisions of Article 52(3) of the ICSID Convention annulled the award. The implication of the annulment was that the dispute was re-submitted to ICSID arbitration. Despite the criticism that the annulment proceedings drew, particularly with respect to exceeding their jurisdiction by re-examining the merits of the case and obscuring the lines between an appeal and annulment ${ }^{64}$, the case demonstrates the contribution of African states as parties to investment disputes before the ICSID.

In addition to the foregoing, an African state - the Democratic Republic of Congo - was the first to file an application for revision of an award in $1988^{65}$ and so was the first conciliation proceedings under the Convention. ${ }^{66}$ An important fact that derives from the examination of some of the First-Generation cases is that African states have simply carried on the momentum as far as their engagement with the ICSID regime is concerned. They are indeed primary users of the system and the First-Generation of disputes involving African state parties have been crucial to the development of the first two decades of ICSID dispute system.

\section{Second-Generation: 2000s - 2010}

In this section, I move the analyses forward by examining a different the set of cases involving African states as parties from the 2000s. By way of overview, this category of disputes not only

60 Another dispute involving an African State that is relevant and illustrative of the jurisprudence on partial annulment in ICSID, is Maritime International Nominees Establishment v. Republic of Guinea, Dec. 22, 1989, 4 ICSID Rep. (1997).

${ }^{61}$ Christoph Schreuer, “Three Generations of ICSID Annulment Proceedings”, [*], pp. 17-42;

62 Article 52(1) provides that "Either party may request annulment of the award by an application in writing addressed to the Secretary-General on one or more of the following grounds:

(a) that the Tribunal was not properly constituted; (b) that the Tribunal has manifestly exceeded its powers; (c) that there was corruption on the part of a member of the Tribunal; (d) that there has been a serious departure from a fundamental rule of procedure; or (e) that the award has failed to state the reasons on which it is based."

${ }^{63}$ For a useful summary of the case and dissenting opinion, see, Jan Paulsson, "The ICSID Klockner v. Cameroon Award: the Duties of Partners in North-South Economic Development Agreements", (1984) 1 Journal of International Arbitration, 145; Friedrich Nigggemann, "The ICSID Klockner v. Cameroon Award: the Dissenting Opinion," (1984) 1 Journal of International Arbitration, 331.

${ }^{64}$ Mark B. Feldman, "The Annulment Proceedings and the Finality of ICSID Arbitral Awards, (1987) 2 ICSID Review Foreign Investment Law Journal 85.

65 American Manufacturing \& Trading, Inc v. Democratic Republic of Congo, ICSID Case No. ARB/93/1.

${ }^{66}$ SEDITEX v. Madagascar, ICSID Case No CONC/82/1 
clarify rules such as those relating to amicus curiae and certain standards of treatment of investments, but also, they reinforce the rule of law as an instrument against corruption in foreign investment relations, expropriation, clarification of the concept of "investment" procedural matters going to transparency of international investment arbitration, and broader societal concerns beyond pure investment focus. For example, in the 2005 case of Wena Hotels Limited v. Arab Republic of Egypt, the first application for interpretation was filed. ${ }^{68}$ Similarly, in the case of BSG Resources Limited (in administration), BSG Resources (Guinea) Limited and BSG Resources (Guinea) SARL v. Republic of Guinea, for the first time, parties agreed to apply the 2014 UNCITRAL Rules on Transparency in Treaty-based Investor-State Arbitration in an ICSID arbitration. ${ }^{69}$ In the remaining section of the Second-Generation, I will focus on Salini Costruttori SpA and Italstrade SpA v. Kingdom of Morocco $;{ }^{70}$ World Duty Free v. Kenya $;^{71}$ Biwater Gauff (Tanzania) Limited v. United Republic of Tanzania ${ }^{72}$ as disputes involving African States and exemplifying their contribution to the development of international investment law.

The Salini v Morocco dispute provides a unique and original addition to the list of cases with African parties as respondents which yielded a consequential award - this time in relation to the test for the determination of "investment." The ICSID Convention did not define the notion of "investment." 73 The dispute arose from an agreement entered into in 1994 between the Claimants and the Kingdom of Morocco for the construction of part of a highway connecting different regions in Morocco. The construction work was undertaken by the Claimants and duly completed in 1999. It was their effort to recover claims for compensation that had been refused by relevant agencies of the Kingdom of Morocco that led to this dispute. In 2000, the Claimants submitted a request on the basis of the ICSID arbitration clause in the bilateral investment treaty between the government of Italy and the Kingdom of Morocco. In response, the Moroccan government raised a number of objections. They contended that the Tribunal lacked subject matter jurisdiction as a contract for the construction of a highway could not be characterized as an investment but as contract for services. In addition, they argued that Tribunal did not have ratione personae jurisdiction. ${ }^{74}$ In its decision on the meaning of "investment", the Tribunal provided four-way criteria ${ }^{75}$ that has been critically engaged in the literature as not mandatory. ${ }^{76}$ Upon applying the test, the Tribunal found that the construction work engaged in by the Claimant could not qualify as an investment within the meaning of Article 25 of the Washington Convention.

\footnotetext{
${ }^{67}$ For example, see, American Manufacturing and Trading (AMT) v. République du Zä̈re, [*]

${ }^{68}$ ICSID Case No. ARB/98/4

69 ICSID Case No. ARB/14/22

${ }^{70}$ ICSID Case No. ARB/00/4

71 ICSID Case No. ARB/00/7. The Metal-Tech Ltd $v$ the Republic of Uzbekistan falls into this category as well. ICSID Case No. ARB/10/3, Award of 4 October 2013

72 ICSID Case No. ARB/05/22

73 Julian Davis Mortenson, "The Meaning of "Investment": ICSID's Travuax and the Domain of International Investment Law”, (2010) 51:1 Harvard Journal of International Law, pp. 257-318

${ }^{74}$ Emmanuel Gaillard and Yas Banifatemi, "Introductory Note to ICSID: Salini Contruttori SPA and Italstrade SPA v. Kingdom of Morocco (Proceeding on Jurisdiction)”, (2003) 42:3 International Legal Materials, pp. 606-608.

75 Drawing on a mix of the activity in question in this case and scholarly writings, the Tribunal developed the following criteria: the existence of contributions; a certain duration in the performance of the contract; participation in the risks of the transaction; the transaction contributes to the economic development of the host state.

${ }^{76}$ Alex Grabowski, "The Definition of Investment under the ICSID Convention: A Defense of Salini”, (2014) 15:1 Chicago Journal of international Law, pp. 289-308.
} 
Another important case in the Second-Generation that has generated significant analyses in the context of ICSID jurisprudence is the World Duty Free $v$ Kenya. Prior to discussing the case, it is important to provide a brief context of corruption and anti-corruption, particularly as it relates to developing countries of the African continent. ${ }^{77}$ Foreign direct investment and economic development, especially in developing countries, are two sides of the same coin that have implications for economic growth. While corruption remains an important scourge across the African continent, in the majority of known cases of major corruption in African States, there is an international dimension or party that is also involved. In the context of foreign investment contracts, allegations of corruption in the procurement process remains an important obstacle to the realization of the maximum economic and social development in African states. In reality, the multinational and transnational corporations that are involved in the bribery for the award of the contracts and projects have hardly been held accountable. ${ }^{78}$

Bearing the foregoing in mind, the World Duty Free v. Kenya, is refreshing in its deployment of the ICSID arbitration for the pursuit of rule of law and anti-corruption in foreign investment. In 1989, Kenya concluded an agreement for the construction, maintenance, and operation of dutyfree complexes at its Nairobi and Mombassa International Airports - with a company called the "House of Perfume" (incorporated under the laws of the Isle of Man, United Kingdom). In June 2000, an Isle of Man corporation, World Duty Free Company Ltd, launched arbitral proceedings against the Republic of Kenya under the ICSID convention. It did so pursuant to an arbitration clause in a contract by which World Duty Free had been awarded the exclusive concession to run the duty-free operations at Kenya's international airports in Nairobi and Mombassa. ${ }^{79}$ As part of its case, the Claimant adduced evidence to the effect that the contract was procured after the payment of bribe. However, they contended that they were "gifts" which were cultural in Kenya and had in fact been legitimized when the government accepted them. ${ }^{80}$ On their part, the government of Kenya did not join issues with the Claimant on this point. Rather, they asked for an immediate dismissal of the claims on the ground that they were contrary to public policy,

\footnotetext{
${ }_{77}$ Odumosu, Ibironke T. "International Investment Arbitration and Corruption Claims: An Analysis of World Duty Free v. Kenya," (2011) 4:3 The Law and Development Review, pp. 88-129; Tamar Meshel, "The Use and Misuse of the Corruption Defence in International Investment Arbitration", (2013) 30 J. INT'L ARB. 267; Margareta Habazin, "Investor Corruption as a Defense Strategy of Host States in International Investment Arbitration: Investors' Corrupt Acts Give an Unfair Advantage to Host States in Investment Arbitration", (2017) 18:805 Cardozo Journal of Conflict Resolution, pp 805-828.

${ }^{78}$ For literature that discusses the intertwined nature of corruption and foreign direct investment, see, Mohsin Habib and Leon Zurawicki, "Corruption and Foreign Direct Investment", (2002) 33:2 Journal of International Business Studies, pp. 291-307;

${ }^{79}$ For an account of the facts and insights of this case by the counsel on record for the Republic of Kenya, see, Constantine Partasides, World Duty Free v. The Republic of Kenya: a Unique Precedent, Chatham House International Law Discussion Group, 28 March 2007. Online: https://star.worldbank.org/corruptioncases/sites/corruption-cases/files/documents/arw/Moi_World Duty_Free_Chatham_House Mar_28 2007.pdf;

Travis Edwards, "Corruption as a Jurisdictional Barrier in Investment Arbitration: Consequences and Solutions" The Global Anticorruption Blog, July 17, 2007. Online: https:/globalanticorruptionblog.com/tag/world-duty-free-vkenya/

80 The Claimant's counsel built there case of three arguments in contending that it should not be dismissed: "(i) First we were told that "gifts" of this kind are customary practice and culturally sanctioned in Kenya, and thus could involve no illegality; (ii) Secondly, as this "gift" had been paid to the head of state, the personification of the state, the state itself had received the payment, and had relevant knowledge of the payment, and had therefore affirmed the contract - even if there had been any earlier illegality; and (iii) thirdly and finally, the Claimant asked the Tribunal to "accept" the "messy realities of international business in the 1970s and 1980s in the developing word", and to "balance the venality" of the "giving" and "taking" of a bribe so as not to punish the payer to the advantage of the "receiver"” Ibid, pp. 3-4.
} 
unenforceable and that the "machinery of international justice was not available to enforce the fruit" of illegality. ${ }^{81}$ The decision of the Tribunal was rendered six years later by a panel of three Arbitrators that the contract which was the basis of the dispute by the Claimant had been procured based on the payment of bribe to the then Kenyan Head of State - President Daniel arap Moi. Premised on this fact, the claims of the Claimant were dismissed in their entirety as one that is contrary to international public policy and therefore unenforceable. An interesting fact that the World Duty Free adds to the jurisprudence of ICSID Tribunal relates to the power of an arbitrator, even in cases where parties have not raised illegality, to suo moto address such public policy issue and not feel constrained to its brief as derived from the agreement of the parties to the dispute. Further, the case stands as the first of its kind in ICSID where a matter was struck out by an Arbitral Tribunal on non-jurisdictional basis. ${ }^{82}$

Furthermore, the case Biwater Gauff (Tanzania) Limited v. United Republic of Tanzania, provides a rich example of investment dispute involving an African state with consequential tribunal awards - substantive and procedural - beyond the case itself. In this regard, the dispute raises issues relating to sustainable development, expropriation in the context of foreign investment, transparency in and legitimacy of investor-state dispute settlement, consideration of broader societal concerns relating to environmental health and water. ${ }^{83}$ The case also adds to the jurisprudence of the ICSID on the definition of "investment" under the ICSID Convention as well as amicus curiae participation in international investment disputes. In addition, for the first time, a deliberation and order were issued by a Tribunal on the question of disclosure of arbitral proceedings thereby contributing to the debate for greater transparency in international investment arbitration. ${ }^{84}$

The World Bank provided Tanzania some funding for the repair, upgrade, and expansion of the water and sewage infrastructure of the city of Dar es Salaam. ${ }^{85}$ A condition of the funding was that the United Republic of Tanzania will appoint a private company for the purposes of managing and operating the infrastructure improvements. The Claimant - Biwater Gauff (Tanzania) Limited, a private water company - emerged as the preferred bidder for the management of the infrastructure improvements. BGT is a joint venture created by Biwater International Limited and HP Gauff Ingenieure $\mathrm{GmbH} \& \mathrm{Co}$. for the purposes of the Tanzanian project; Biwater owns $80 \%$ of BGT and Gauff owns $20 \%$. The Claimant subsequently entered into agreements with various Tanzanian subcontractors as part of the conditions of its contract. Three years into the implementation of the project - May 2005, the Tanzanian government and the Dar es Salaam Water and Sewage Authority terminated the contract of one of the subcontractors and proceeded to expropriate its assets. ${ }^{86}$ In its claim before the ICSID Tribunal

\footnotetext{
81 Ibid, p. 3.

82 Danielle Young, "Is Corruption an Emerging Cause of Action in Investor-State Arbitration?", The Global Anticorruption Blog, January 22, 2016. Online: https://globalanticorruptionblog.com/2016/01/22/is-corruption-anemerging-cause-of-action-in-investor-state-arbitration-2/

83 Frances Aldson, "Biwater v. Tanzania: do corporations have human rights and sustainable development obligations stemming from private sector involvement in natural resource provision?" (2010) 2 Environmental Liability, pp. 58-66.

${ }^{84}$ Katia Fach Gómez, "Rethinking the Role of Amicus Curiae in International Investment Arbitration: How to Draw the Line Favourably for the Public Interest", (2012) 35:2 Fordham International Law Journal, pp. 513-524;

${ }^{85}$ World Bank, "Tanzania - Dar es Salaam Water Supply and Sanitation Project", Report No. PID7578, 4 February 2003, online: http://documents.worldbank.org/curated/en/216391468778537045/pdf/multi0page.pdf;

86 John Vidal, "Flagship water privatization fails in Tanzania", The Guardian, 25, May 2005, https://www.theguardian.com/politics/2005/may/25/uk.world
} 
in August 2005, the Claimant (being partly British and German company) argued that the Tanzanian government had breached the terms of a 1994 bilateral investment treaty between the United Kingdom and Tanzania for the Promotion and Protection of Investments and was also in violation of the provisions of the Tanzanian Investment Act. On its part, the Tanzanian government contended that the Citywater contract was terminated because it did not have sufficient funds to execute the project with such significant implications for public health and welfare. Hence, it was left with no option than to expropriate the project in the interest of the public. In the ICSID proceeding, amicus briefs were received from Tanzanian and international non-governmental organizations in support of the Tanzanian Government. ${ }^{87}$ For the NGOs, they argued that investor responsibilities in the sustainable development and human rights contexts ${ }^{88}$ extend to specific issues such as duty to apply proper standards and due diligence procedures, the principle of pacta sunt servanda, duty of good faith, and a duty to abide by the investor's general responsibilities.

Refusing the Republic of Tanzania's argument, the Tribunal ruled in favour of the Claimant that the actions of the Tanzanian government amounted to an expropriation of the Claimant's investment under the bilateral investment treaty. In particular, the tribunal ruled that the Republic of Tanzania had not acted in a fair and equitable manner in engaging in unreasonable and discriminatory conduct for informing the public of the termination of the contract when in fact it had not done so. However, the Tribunal did not award any monetary compensation to the Claimant as there was no value ascribed to the company as at the time of expropriation. ${ }^{89}$

First, the dispute adds to the ICSID jurisprudence on the clarification of the concept of "investment." Article 25 of the ICSID Convention provides that ICSID Tribunals can only assume jurisdiction over certain legal disputes. In this regard, a jurisdictional requirement is that the dispute in question must have been borne directly out of an "investment" - a term that is not defined in the ICSID Convention. The United Republic of Tanzania had argued that meaning of "investment" under the ICSID Convention has now been determined by the case law and required the establishment of the "Salini" test. ${ }^{90}$ The Tribunal, however, rejected the argument of the Tanzanian government on the ground that the application of the Salini test to define "investment" is not mandatory or static as they are merely factors that should be taken into account. In defining "investment", the critical point of reference that should inform the meaning

87 The amicus curiae brief filed by The Lawyers' Environmental Action Team; The Legal and Human Rights Centre; The Tanzania Gender Networking Programme; The Center for International Environmental Law; and The International Institute for Sustainable Development is available online: https://www.iisd.org/pdf/2007/investment amicus final march_2007.pdf. “The brief argues that BGT's acts and omissions caused its investment to fail and that investors in the water sector have a heightened level of responsibility because the success of a business venture in this area has a direct impact on the achievement of an essential human right - the right to clean and safe water. The brief further argues that taking into consideration human rights and sustainable development, termination of the contract by a government, if done in good faith to prevent the worsening or abuse of human rights, should not be found to be a contractual breach, especially when a contract's purpose was to promote and enhance the achievement of such rights." Business \& Human Rights Resource Centre, "BiwaterTanzania arbitration", online: https://www.business-humanrights.org/en/biwater-tanzania-arbitration.

${ }^{88}$ Graham Mayeda, "Sustainable International Investment Agreements: Challenges and Solutions or Developing Countries" M. Gehring, M.-C. Cordonier Segger \& A. Newcombe (Eds.), Sustainable development in world investment law, (2011, Kluwer Law International), p. 535.

89 Expropriation claims remains a contentious aspect of the Tribunal awards and the Third-Generation cases involving Zimbabwe sheds some more light on this aspect of ICSID tribunal jurisprudence.

90 This requires the establishment of a 5-stage test: (1) adequate duration; (2) regularity of profit and return; (3) risk; (4) substantial commitment of resources, financial or otherwise; and (5) contribution to the host state's development. 
ascribed is the relevant bilateral investment treaty. Indeed, rather than the narrow and strict approach in Phoenix $v$ Czech Republic ${ }^{91}$, the Tribunal adopted a broad approach to defining "investment."

Second, the dispute provided an important procedural clarification on the participation of amicus curiae in international investment arbitration under the ICSID Arbitration Rules. It should in fact be noted that although it was not necessarily a direct consequence of the final outcome of the case, that the Arbitration Rules were amended to clarify that tribunals are empowered to allow submissions by amicus curiae and provide guidelines for their intervention is an important development from this case. ${ }^{92}$ That the amici in this case were allowed to intervene was a result of this revision which has become part of the international investment jurisprudence. The Claimant's contention that the interventions by amici will not be relevant was accordingly rejected by the Tribunal. The significance of the Tribunal's acceptance of and copious references to the amici contributions are further significant in that "it recognizes and affirms the public interest in investor-state disputes, helps normalize the idea of non-party participation, helps ensure that investor-state disputes take into account broader issues such as sustainable development and human rights where relevant, promotes investor and government accountability and enhances the perceived legitimacy of the system."93

Third, in addition to the substantive issues dealt with in this case, there is also a significant procedural contribution from the dispute. ${ }^{94}$ One of the questions that the Tribunal adopted Procedural Order No. 3 to deal with was the unilateral decision by the United Republic of Tanzania to disclose certain documents relating to the proceeding in the public realm. The Tribunal also addressed for the first time the issue regarding the publication of documents during the arbitral proceedings in detail. As Christina Knahr argues, the Order is noteworthy for two reasons: "first, the tribunal's thoroughly weighing of transparency against procedural integrity and non-aggravation of the dispute; and second, its separate examination of various kinds of documents produced during the proceedings with respect to their suitability for publication." 95 Indeed, the order of the Tribunal is a "valuable contribution to increasing clarity on how to address the issue of publication of documents in arbitral proceedings" and "the novelty of the order lies in the differential treatment of various kinds of documents produced by the parties as well as the tribunal in the course of the proceedings and the tribunal's distinct conclusions regarding these documents." 96

\footnotetext{
${ }^{91}$ ICISD Case No. ARB/06/5.

${ }^{92}$ N. Bernasconi-Osterwalder, "Transparency and amicus curiae in ICSID arbitration: Lessons learned from Biwater Gauff v. Tanzania," in M. Gehring, M.-C. Cordonier Segger \& A. Newcombe (Eds.), Sustainable development in world investment law, (2011, Kluwer Law International), p. 189.

${ }^{93}$ Lise Johnson, Commentary on "Biwater v. Tanzania", International Institute for Sustainable Development, October 18, 2018. Online: https://www.iisd.org/itn/2018/10/18/biwater-v-tanzania/

${ }^{94}$ Fiona Marshall, "The Precarious State of Sunshine: Case Comment on Procedural Orders in the Biwater Gauff (Tanzania) Ltd. v. Tanzania Investor-State Arbitration”, (2007) McGill Journal of Sustainable Development Law, 3:2 pp. 181-203

${ }_{95}$ Christina Knahr, "Introductory Note to International Centre for Settlement of Investment Disputes (ICSID): Biwater Gauff (Tanzania) Ltd. v. United Republic of Tanzania, ICSID Case No. ARB/05/22, Procedural Order No. 3 (2007) 46:1 International Legal Materials, pp. 12-14, p. 12.

${ }_{96}$ Ibid, p. 13.
} 


\section{Third-Generation: 2010 - to Date}

The Third-Generation of investment disputes involving African states start from 2010 to the present moment. Like the previous generations, the Third-Generation disputes represent a significant and radical extension of the frontiers of issues in ICSID investment disputes jurisprudence. This category of investment disputes interestingly incorporates new themes such as - sustainable development, human rights, protection of indigenous rights and environmental standards to mention a few - in the broader discourse on international investment. Although human rights concerns have not traditionally been included in international investment treaties, human rights and indigenous peoples' rights where the dispute relates to land will remain critical in the debate on the future of investment arbitration as the Second and Third Generation of investment disputes involving African countries show. ${ }^{97}$

For the purpose of this article, I will focus on the following disputes: Menzies Middles East and Africa SA and Aviation Handling Services International Ltd. v. Republic of Senegal, ${ }^{98}$ and Bernhard von Pezold and others v. Zimbabwe. ${ }^{99}$ These disputes challenge the systemic integration between international investment law and other areas of the law. They have also opened new vista with respect to broader developments in Africa, new models of investment agreements and even the use of remedies such as restitution which is scarcely ordered in ICSID arbitration.

The dispute in Bernhard von Pezold and others v. Zimbabwe ${ }^{100}$ arose from complaints of expropriation without compensation by the Government of Zimbabwe of large agricultural estate belonging to the claimants. The claimants allege that they have been unfairly targeted as part of Zimbabwe's land reform process that had begun since the 1980s. Bernhard von Pezold and his family, who are dual Swiss and German nationals, bought 78,275 hectares of farmland in Zimbabwe starting in 1988 under the Switzerland-Zimbabwe and Germany-Zimbabwe bilateral investment treaties. ${ }^{101}$ Following an amendment to the constitution of Zimbabwe in 2005, the Zimbabwean state acquired title to most of the claimants' land, revoked their right to challenge the acquisition, and criminalized their continued occupancy of the land. While Zimbabwe admitted the allegation of expropriation, they contended that it had been done for the purposes of

97 Silvia Steininger, "What's Human Rights Got To Do With It? An Empirical Analysis of Human Rights References in Investment Arbitration" (2018) 31 Leiden Journal of International Law, pp. 33-58, p. 34; P. Muchlinski, 'Holistic Approaches to Development and International Investment Law: The Role of International Investment Agreements', in J. Faundez and C. Tan (eds.), International Economic Law, Globalization and Developing Countries (2010), 180

98 ICSID Case No. ARB/15/21

99 ICSID Case No. ARB/10/15. Other cases involving African states in this generation that have either affirmed principles of international investment law or added to the ICSID jurisprudence in other notable ways include: Millicom International Operations B.V. and Sentel GSM SA v. The Republic of Senegal, ICSID Case No. ARB/08/20; Helnan International Hotels A/S v. Arab Republic of Egypt, ICSID Case No. ARB/05/19; International Quantum Resources Limited, Frontier SPRL and Compagnie Miniere de Sakania SPRL v. Democratic Republic of the Congo, ICSID Case No. ARB/10/21.

100 J. Cameron Mowatt and Celeste Mowatt, "Boarder Timbers and Others v. Zimbabwe and von Pezold and Others v. Zimbabwe", (2013) 28:1 ICSID Review - Foreign Investment Law Journal, pp. 33-44.

101 Jacob Greenberg, "ICSID tribunal orders Zimbabwe to return expropriated farms", May 16, 2016, International Institute for Sustainable Development, online: https://www.iisd.org/itn/2016/05/16/icsid-tribunal-orders-zimbabweto-return-expropriated-farms-bernhard-von-pezold-and-others-v-zimbabwe-icsid-case-no-arb-10-15-jacobgreenberg/ 
transferring the land to indigenous Zimbabweans. Further amendments to Zimbabwe's constitution in 2013 provide full compensation for land seized from "indigenous Zimbabweans" and reaffirmed the right of foreign investors to full compensation under the bilateral investment treaties. ${ }^{102}$

With respect to the expropriation claim, the Tribunal rejected Zimbabwe's argument that the estate was lawfully acquired for public purpose and to compensate for the historically disadvantaged indigenous people of Zimbabwe. In ruling in favor of the Claimant, the Tribunal found Zimbabwean government's expropriation of the estate of the Claimant as unlawful, without compensation, racially discriminatory, and a violation of the bilateral investment treaties Zimbabwe signed with Germany and Switzerland. The tribunal also found that the actions of the Zimbabwean government violated fair and equitable treatment provisions of the bilateral investment treaties. The remedy order for the violations was also unconventional. The tribunal ordered restitution as an appropriate and feasible remedy for the purposes of this case.

The dispute also enriches the growing jurisprudence of ICSID on amici curiae and interventions by NGOs on the basis of human rights violations. In Bernhard von Pezold and others $v$. Zimbabwe, the European Centre for Constitutional and Human Rights (ECCHR) and several Zimbabwean indigenous communities sought permission to be join as amici curiae in the arbitral proceedings. The ECCHR had sought to join because of the involvement of European investors. ECCHR, together with the indigenous chiefs, sought to draw the tribunal's attention to the fact that these properties are located on the ancestral territories of the native peoples. On this issue, the Tribunal rejected the request to participate as amici curiae on the grounds that: (i) the amici had not demonstrated that their submission would assist the tribunal in determining a factual or legal issue related to the proceedings, address a matter within the scope of the dispute, or would flow from any significant interest they had in the proceeding ${ }^{103}$; and (ii) that the amici were not independent from Zimbabwe. Luca Bastin argues that the Tribunal created an extra layer of burden for would-be amici curiae by requiring an appearance of or "apparent independence" of the amicus into the provisions of ICSID Arbitration Rule $37 .{ }^{104}$ The decision of the tribunal has also been described as conservative compared to other instances where ICSID tribunal allowed the intervention of NGOs in previous cases on the basis of the human rights law.

Another ICSID case in the current dispensation that involved an African state as Respondent and illustrated the overlap, though divergent, of principles of Most-Favoured-Nation (MFN) in international trade law via-s-vis international investment law is Menzies Middles East and Africa SA and Aviation Handling Services International Ltd. v. Republic of Senegal. ${ }^{105}$ In the context of this case, ICSID tribunal upheld Senegal's objection to jurisdiction and dismissed the applicability of MFN clause provision in World Trade Organization (WTO) General Agreement in Trade and Services (GATS) as a way to find that Senegal consented to ICSID international arbitration. In 2003, the claimants acquired Aviation Handling Services SA (AHS SA). The company was created under Senegalese law for the purpose of ground handling activities in

\footnotetext{
102 Zimbabwe's Constitution of 2013, online: http://extwprlegs1.fao.org/docs/pdf/zim127325.pdf; James Tsabora, "Reflections on the Constitutional Revolution of Property and Land Rights under the 2013 Zimbabwean Constitution", (2016) 60:2 Journal of African Law, pp. 213-229.

103 That is a straight application of the rules for joining amicus curiae under ICSID Arbitration Rule 37(2).

104 Lucas Bastin, "Amici Curiae in Investor-State Arbitrations: Two Recent Decisions", (2013) Australian International Law Journal, pp. 95-104.

105 Rebecca Hekman, Nadege Huart and Janet Whittaker, "Menzies Middle East and Africa S.A. and Aviation Handling Services International Ltd. v. Republic of Senegal”, (2017) 16:1 World Trade Review, pp. 143-147.
} 
Senegalese airports. Problem ensued for the company when its activities was temporarily suspended based national investigations relating to illicit enrichment and collusion in illicit enrichment under Senegalese local laws. When AHS SA's Senegalese principals were eventually found guilty and the assets of the company confiscated, the claimants sued before ICSID contending the illegality of the actions of the Senegalese government under general international law and bilateral investment treaties with Netherlands and the United Kingdom. Senegal's objections to jurisdiction were three-fold: that Senegal did not consent to arbitration; that there was no investment made in Senegal by the claimants; and also disputed the Senegalese nationality of the claimants. The claimants relied on provisions of the WTO GATS, Senegalese investment code, bilateral investment treaties between Senegal and Netherlands on the one hand, and Senegal and the United Kingdom on the other hand. In refusing the claimant's argument, the tribunal found that the GATS does not provide the basis for consent to arbitration in any form and could not be the basis for imputing an unequivocal consent to Senegal. ${ }^{106}$ According to the tribunal, the decision to not uphold its obligations under GATS is an exercise of the Senegalese government's sovereign prerogative, the breach of which appropriate dispute mechanism is provided for under GATS.

Based on the forgoing analyses, an undeniable and important narrative emerges regarding the contribution of international investment disputes involving African States to the development of the international investment law regime: ICSID arbitration rulings involving African states have been critical to the development of international investment law. ${ }^{107}$ These disputes have provided a significant opportunity for the elaboration of ICSID Convention Arbitration Rules, the relationship of international investment law to other areas of the law such as human rights law, international trade law and public international law broadly conceived. Specifically, from clarifications regarding the notion of an investment, standards of treatment, standards of protection - expropriation, procedural aspects relating to admissibility, remedies, national investment laws, transparency before the ICSID with consequential actions leading to the amendment of ICSID Arbitration Rules, and corruption to mention a few, African states, mostly as respondents, have been fundamental to the development of international investment law over the years.

\section{Part III \\ Concluding Remarks - Entrenching Africa's Contribution to ICSID}

The primary aim of this article was to provide an account of the contributions of African states to the development of international investment law over the years based on their participation in ICSID disputes. Despite the questions regarding the status of the 'equality' regarding their involvement, African states' participation, both numerical and consent contexts, were critical to the establishment of ICSID. In the operational phase of ICSID, the analysis of the participation of African states in ICSID, particularly as parties to disputes has drawn significant critical reflection that draw attention to the power relations embedded in the system, apparent lack of

\footnotetext{
${ }^{106}$ For a brief summary of the decision, see, Suzy H. Nikièma, "ICSID tribunal dismisses MFN clause in WTO GATS as a means of importing Senegal's consent to arbitration from third party BIT", December 12, 2016, International Institute for Sustainable Development, online: https://www.iisd.org/itn/2016/12/12/mfn-clause-wtogats-importing-consent-arbitration-third-party-bit-menzies-middle-east-africa-aviation-handling-servicesinternational-senegal/

$\frac{107}{10 a n n u ' s ~ r e c e n t ~ a r t i c l e ~ p r o v i d e s ~ a ~ f a s c i n a t i n g ~ e m p i r i c a l ~ a n a l y s i s ~ o f ~ v a r i o u s ~ s e c t o r s ~ t h a t ~ t h e ~ d i s p u t e s ~ h a v e ~ e m e r g e d . ~}$
} 
diversity ${ }^{108}$ in the calibre, gender, and geographical pool of ICSID arbitrators, and cultural differences. The article acknowledges that these critiques are well-founded and will need to be addressed.

While the project for the reform of ICSID $^{109}$ and entrenchment of the participation of African states, and African arbitrators in ICSID arbitration continues, the article made the point that we must also reclaim the various contributions that the participation of African states in ICSID dispute has made to the overall development of ICSID case law and international investment law. In this regard, the article conceptualizes African states as reverse contributors - a concept that was adopted and analyzed precisely to demonstrate the complexity of the historical and extant context of the participation of African States in ICSID. The concept does not distinguish between the law firms as counsel and the states in the sense of originator of the arguments. It is deliberately broad to indicate the mutuality of the relationship in that regard and to capture the fact that the states have their narratives that provide the factual basis for the arguments by the arbitrators, quite distinctly from the legal and technical aspects.

To interrogate the reverse contributions, the article examined analyzed some disputes involving African states over three generations that are overlapping and not linear. The First Generation of cases are the earliest engagement of African Sates with the ICSID system. These disputes were provided the earlier opportunities for arbitrators to clarify concepts and the applicability of ICSID rules and procedures. The Second Generation of disputes were critical not only to clarify rules such as those relating to amicus curiae and certain standards of treatment of investments, but also, they reinforce the rule of law as an instrument against corruption in foreign investment relations, expropriation, clarification of the concept of "investment", procedural matters going to transparency of international investment arbitration, and broader societal concerns beyond pure investment focus. The Third Generation of disputes analyzed in the article represent a significant and radical extension of the frontiers of issues in ICSID investment disputes jurisprudence. This category of investment disputes interestingly incorporates new themes such as - sustainable development, human rights, protection of indigenous rights and environmental standards to mention a few - in the broader discourse on international investment. Although human rights concerns have not traditionally been included in international investment treaties, the article notes that human rights, sustainability and indigenous peoples' rights concerns, particularly as they are implicated in the disputes involving African States, will remain critical in the debate on the future of investment arbitration.

Looking forward, foreign direct investment in African states is far from its point of maximization. As new opportunities emerge for investment and transnational companies invest

\footnotetext{
${ }^{108}$ For an account of the effort ICSID is making to promote diversity, see, Meg Kinnear, "Advancing diversity in international dispute settlement", The World Bank Blog, March 8, 2019: Online: https://blogs.worldbank.org/voices/advancing-diversity-international-dispute-settlement

109 For current efforts aimed at reforms in the ICSID rules and procedure, see, the ICSID Secretariat's recently published second working paper on proposals for rule amendments (Working Paper \# 2), dated March $15,2019$. ICSID, "ICSID Rues and Regulations Amendment Process", https://icsid.worldbank.org/en/amendments.

Based on a quick review of the contributors listed on the document that provided suggestions for reform, I suggest that ICSID engage more with Arbitrators from Africa to build their input in this process. There are many top law firms on the continent that advise on various transactions with their international counterparts, ICSID can certainly do more in terms of reaching out for their involvement in this and future processes. For example of the type of law firms and arbitrators, see, Kamal Shah, John Miles, \& Tunde Fagbohunlu, Arbitration in Africa: A Review of Key Jurisdictions, (2016: Sweet \& Maxwell)
} 
in the economic development of African states, the ICSID Arbitration system will continue to be an important forum for the settlement of investment disputes given the comfort they afford to the investors. The natural implication of the continuing recourse to the ICSID system is that opportunities for the development of new jurisprudence that address new areas of investment opportunities will arise. One hopes that narrative regarding the participation of African states, as parties to ICSID dispute will consolidate in even more substantive ways to the development of ICSID case law and international investment law jurisprudence in general. 